\title{
Determination of Some Physiochemical Parameters and Selected Heavy Metals from Water Collected from Concrete Fish Ponds in Ozoro Town
}

\author{
${ }^{1}$ Sawere, B.T and ${ }^{2}$ Oghenekowhoyan .O. Collins \\ ${ }^{1}$ Science Laboratory Technology Department \\ Delta State Polytechnic, Ozoro \\ ${ }^{2}$ Emma-Maria Scientific Research Laboratory \\ Ozoro, Nigeria
}

\begin{abstract}
Four samples of different fish pond were analyzed for physiochemical properties. The pH ranged from 6.8 to 7.4; Temperatures ranged from $25^{\circ} \mathrm{C}$ to $27^{\circ} \mathrm{C}$; Conductivity ranged from 148.2 to $191.2 \mu \mathrm{s} / \mathrm{cm}$; TDS ranged from 21.3 to $28.6 \mathrm{mg} / \mathrm{L}$; TSS ranged from 63.1 to $74.7 \mathrm{mg} / \mathrm{L} ;$ DO ranged from 7.5 to $9.3 \mathrm{mg} / \mathrm{L} ; \mathrm{BOD}$ ranged from $2.01-4.01 \mathrm{mg} / \mathrm{L} ;$ Alkalinity ranged from 26.9 to 36.1 while Total Hardness ranged from 2.4 to 3.6. Five heavy metals, Zinc, Nickel, Lead, Iron and Copper were analyzed for different four fish ponds. The concentration of zinc ranged from 0.013 to $0.015 \mathrm{mg} / \mathrm{L}$; Nickel ranged from 0.01 to $0.03 \mathrm{mg} / \mathrm{L}$; Lead ranged from 0.18 to $0.23 \mathrm{mg} / \mathrm{L}$; Iron ranged from 0.29 to $0.48 \mathrm{mg} / \mathrm{L}$ and copper concentration ranged 0.02 to $0.07 \mathrm{mg} / \mathrm{L}$. all the parameter analyzed were within the WHO maximum acceptable concentration in ponds are fit for fish production.
\end{abstract}

Keywords: Physiochemical, Heavy metals, Fishpond, Ozoro.

\section{INTRODUCTION}

Fish is a basic and important food for human nutrition (Abdel-Baki et al., 2011), such as fatty acid in fish that can reduce the risk of heart diseases and stroke due to their contribution in lowering the cholesterol levels in blood and also provides minerals and vitamins (Azaman et al., 2015). The high demand for fish has resulted in the increase in the number of fish ponds in Nigeria. Individual farmers, organized groups and institutions have developed, constructed fish ponds and started fish farming oblivious of the cost. Due to lack of proper expertise and poor management, most farmers carry out fish farming in non-standard environment (Modupe and Indi, 2017).

The importance of water to living things cannot be overemphasized. It is believed to be the reason for life on planet earth. All living things depend on water for its existence (Parariya, 2012). Water being a universal solvent has many substances dissolved in it. These include those that are beneficial and those harmful to man. Its quality therefore depends on factors such as geological morphology, vegetation and land use (Mishsra et al., 2013). Water is the natural habitat of fishes and other aquatic animals, it is therefore of great importance to study water quality while studying fish production especially when done in an artificial setting (Agbaire et al., 2015).

A pond could be referred to as an artificial lake intended for fish breeding (Agbaire et al., 2015), Eze and Ogbaran (2010) further described a pond as a quiet body of water that is so small for wave action and too shallow for major temperature difference from top to bottom. Ponds have been used since time immemorial as a traditional source of water supply in India. However, the water of the ponds, lakes and river are polluted mainly due to discharged waste water from residential areas, sewage outlets, solid wastes, detergents, automobile oil wastes, fishing facilities and agricultural pesticides from farmlands (Shibam et al., 2017).

Poor construction and maintenance of the ponds has also resulted to unconducive physico-chemical properties of the water, thereby interfering with productivity. Lack of knowledge on good hygiene practices has also directly contributed to the 
degradation of fish ponds water quality for habitats thereby resulting to death of fish. Some of the harvested fish from this habitat are small in size, an indicator of stunted growth. According to (Egbere et al., 2008), it is expected that the pH, total alkalinity, electrical conductivity and hardness as well as other physico-chemical parameters lie within acceptable ranges that would support fish productivity (Modupe and Indi, 2017).

Heavy metals have a large effect on the environment and cause many health risks for humans. When heavy metals accumulate to toxic levels, they can cause illness in humans (Vosyliene et al., 2003). The Heavy metals of serious concern with respect to human health, derived from agro-chemical and industrial wastes are $\mathrm{Cd}, \mathrm{Cu}, \mathrm{Fe}, \mathrm{Pb}, \mathrm{Ni}, \mathrm{Zn}$, and $\mathrm{Hg}$. These pollutants are capable of being biomagnified in the aquatic food chain/web and bioaccumulated in high concentrations in fish tissues to the detriment of fish consumers (Modupe and Indi, 2017). Several of the metals such as $\mathrm{Cu}, \mathrm{Fe}, \mathrm{Mn}, \mathrm{Ni}$, and $\mathrm{Zn}$ are essential micronutrients for life processes in living organisms. However, heavy metals like $\mathrm{Cd}, \mathrm{Cr}$, and $\mathrm{Pb}$ do not have any physiological activity but have been proven to be detrimental when their concentrations exceed a certain limit. These heavy metals are linked to deadly diseases such as edema of eyelids, tumor, congestion of nasal mucous membranes and pharynx, stuffiness of the head, and disorders of the gastrointestinal tract.

This study was carried out to determine the concentrations of $\mathrm{Fe}, \mathrm{Zn}, \mathrm{Cd}, \mathrm{Cu}$, and $\mathrm{Pb}$ in water samples from the concrete fish ponds within Ozoro town due to the fact that the town is a fast developing area with a steady growth in population as a result of the presence of a higher institution and the demand for food stuff especially fish and meat is on the increase hence leading to increase in the numbers of persons going into fish farming in the town and the results were compared with acceptable standards. A correlation of the heavy metal concentrations between the different samples was made to evaluate the sources of contamination.

\section{MATERIALS AND METHODS}

Sampling location: water samples were collected from concrete ponds within Ozoro. Ozoro is the headquarters of the Isoko North Local Government Area, one of the two administrative units in the Isoko region of Delta State, southern Nigeria. Ozoro lies between longitude $5^{0} 32^{\prime} 18^{\prime}$ 'North and latitude $6^{0} 12^{\prime} 58^{\prime \prime}$ East. A state owned, Delta State polytechnic is situated in the town, It was originally an agrarian community, but with the emergence of the Polytechnic, there is some form of commercial activities. A total of 2 litres each of water samples from different points at $20 \mathrm{~cm}$ depth of the pond were collected using $250 \mathrm{~mL}$ bottles which were pre-washed with $10 \%$ nitric acid and distilled water.

\section{METHODS}

\subsection{Determination of physico-chemical parameters}

Unstable parameters such as temperature and $\mathrm{pH}$ were measured in-situ. Temperature was determined using the mercury in bulb thermometer while $\mathrm{pH}$ was measured with a portable $\mathrm{pH}$ meter (Hann $\mathrm{pHep} \mathrm{pH}$ Tester). Conductivity was determined using DDS-307 that measures in microsimens/centimeter $(\mu \mathrm{S} / \mathrm{cm})$. Total Dissolved Solids (TDS) and total suspended solids (TSS) were determined gravimetrically (Agbaire et al., 2015).

Samples for dissolved oxygen and biochemical oxygen demand were sampled with a $250 \mathrm{~mL}$ dark coloured reagent bottles. These water samples were fixed at site by adding $1.0 \mathrm{~mL}$ of Winkler's solution 1 (Manganese (II) tetraoxosulphate (VI), Monohydrate - MnS04. H2O) and 1.0mL of Winkler's solution II (Sodium hydroxide and Sodium iodide) using a micro-pipette. To this solution $1.0 \mathrm{~mL}$ of concentrated tetraoxosulphate (VI) acid was added below the solution inside the reagent bottle with a pipette. This is to dissolve the precipitate of Manganese (II) hydroxide formed.

All samples were then taken to laboratory in ice slurry for further determination. Dissolved oxygen (DO)) was then determined on the fixed sample using the Winkler's titration (Dunivant, 2005). The biochemical oxygen demand (BOD) was then determined on the DO sample after incubation in the dark for 5 days at Co20 \pm .

Alkalinity was determined by titration procedure where a known volume of water sample was titrated with $0.02 \mathrm{M} \mathrm{HCl}$ (Singh and Gupta., 2010). Total water hardness was measured by titrating $0.01 \mathrm{~N}$ ethylenediammetetracetic acid (EDTA) using Eriochrome black $\mathrm{T}$ as indicator.

\subsection{Heavy metals Quantification in Water Samples}

Acid preserved water sample $(100 \mathrm{~mL})$ was taken in a beaker and $10 \mathrm{~mL}$ of nitric acid was added. It was then brought to a slow boil and evaporated on a hot plate to the lowest volume possible of $15 \mathrm{~mL}$ before precipitation occurred. Heating was continued with the addition of concentrated nitric acid till digestion was completed indicating a light colored clear solution. Care was taken not to let sample get dried during the digestion. Beaker wall was washed with distilled water and volume was made up to $100 \mathrm{~mL}$ by adding distilled water. The sample was then filtered and the filtrate was collected for analysis using a UV-Visible spectrophotometer (A725N). 
International Journal of Advances in Scientific Research and Engineering (ijasre), Vol 5 (5), May-2019

4. RESULTS AND DISCUSSION

Table 1: showing results for physic-chemical parameters

\begin{tabular}{|c|c|c|c|c|c|}
\hline Parameters & $P 1$ & $P 2$ & P3 & $P 4$ & $\begin{array}{c}\text { WHO acceptable } \\
\text { limit }\end{array}$ \\
\hline $\mathrm{Ph}$ & 7.4 & 6.9 & 7.2 & 6.8 & $6.5-8.5$ \\
\hline Temperature ${ }^{0} \mathrm{C}$ & 25.0 & 27.0 & 27.0 & 26.0 & $<35$ \\
\hline Conductivity $\mu \mathrm{s} / \mathrm{cm}$ & 178.3 & 148.2 & 169.5 & 191.2 & 300 \\
\hline TDS mg/L & 25.1 & 28.6 & 26.8 & 21.3 & 500 \\
\hline $\mathrm{TSS} \mathrm{mg} / \mathrm{L}$ & 69.3 & 74.7 & 81.2 & 63.1 & \\
\hline $\mathrm{DO} \mathrm{mg} / \mathrm{L}$ & 8.2 & 8.6 & 7.5 & 9.3 & $4-6$ \\
\hline BOD mg/L & 2.01 & 2.06 & 4.01 & 3.08 & 6 \\
\hline Alkalinity & 36.1 & 27.3 & 32.4 & 26.9 & 600 \\
\hline Total hardness & 3.2 & 3.6 & 2.9 & 2.4 & 600 \\
\hline
\end{tabular}

KEY: P1: Pound 1, P2; pound 2, P3: pound 3, P4: pound 4

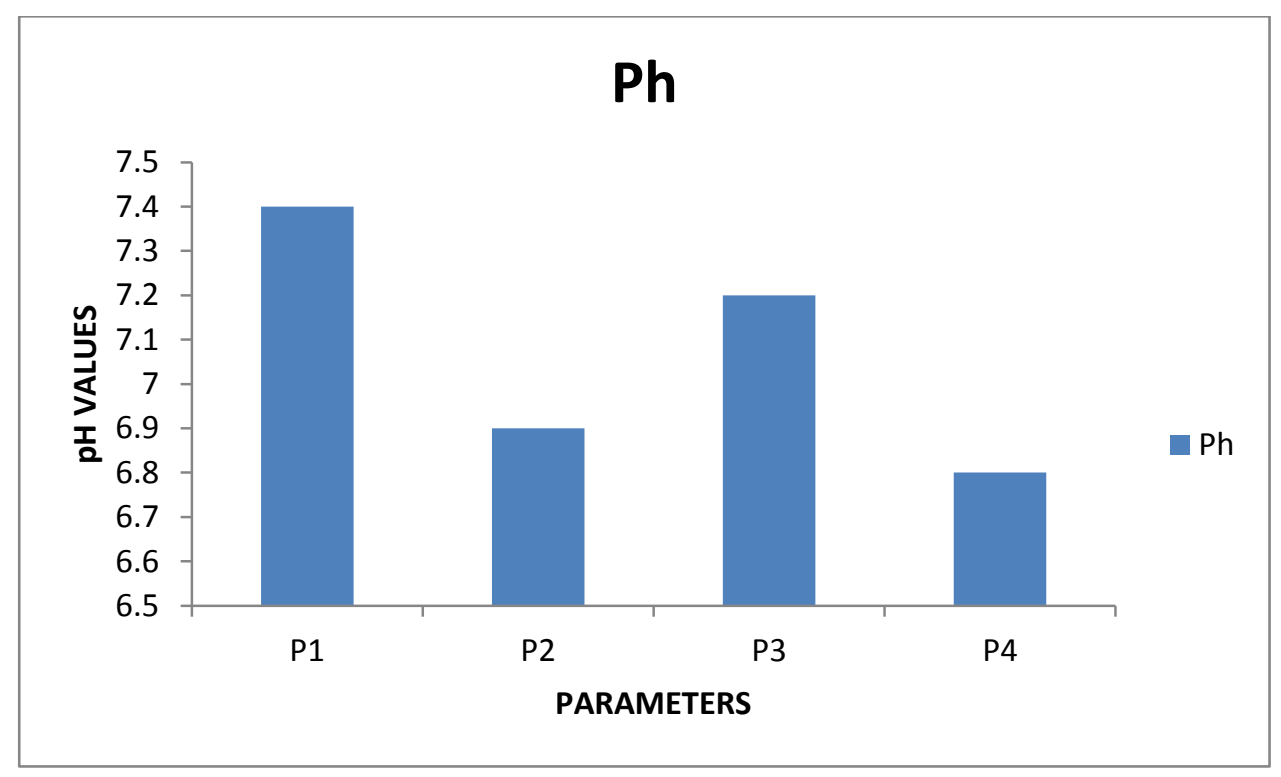

Fig. 1 pH values for parameter P1, P2, P3, P4

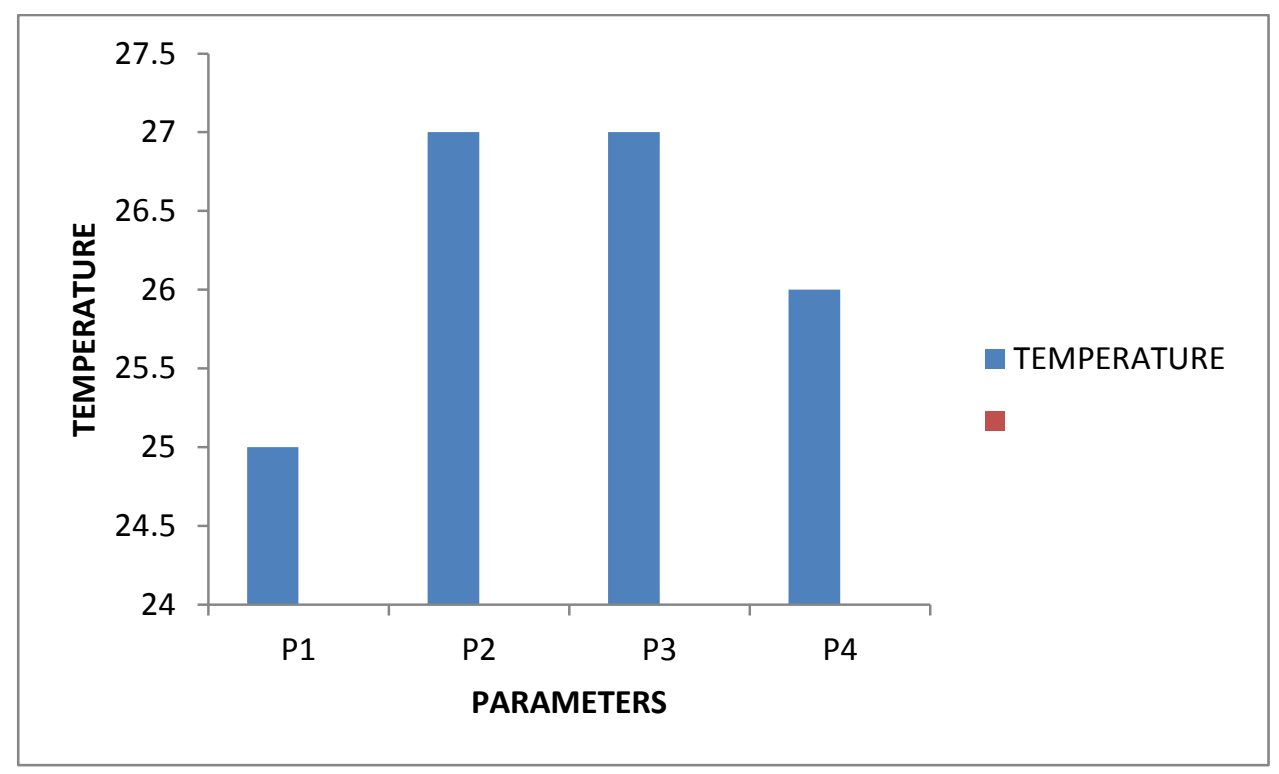

Fig. 2: Temperature values for the parameter P1, P2, P3, P4 
International Journal of Advances in Scientific Research and Engineering (ijasre), Vol 5 (5), May-2019

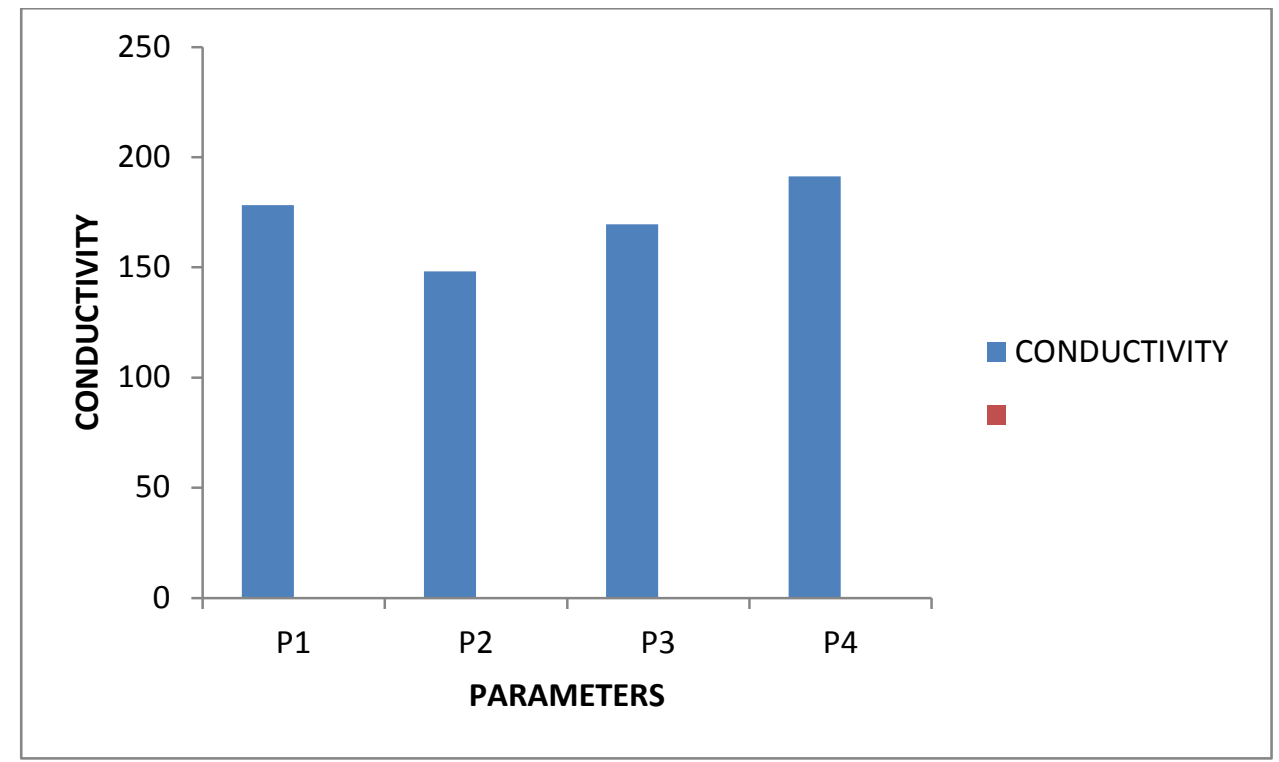

Fig. 3: Conductivity values for Parameter P1, P2, P3, P4

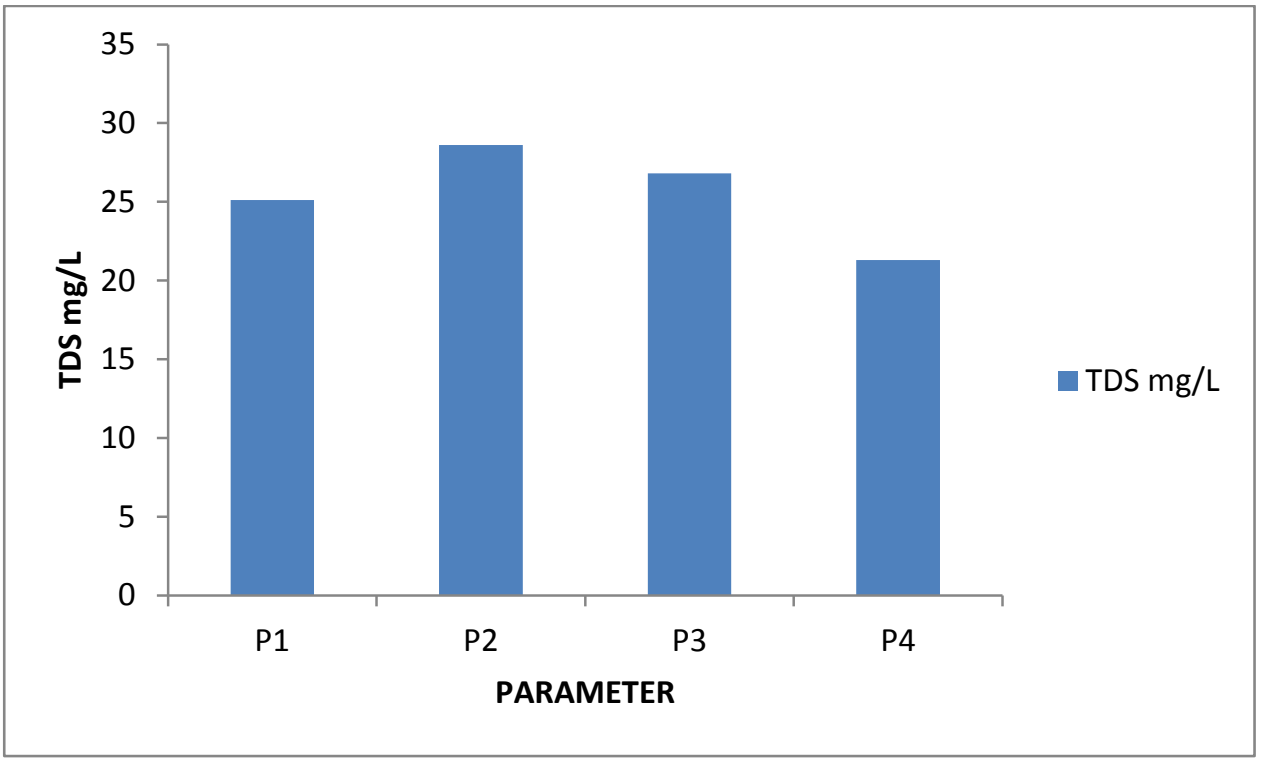

Fig. 4: TDS values for Parameter P1, P2, P3, P4

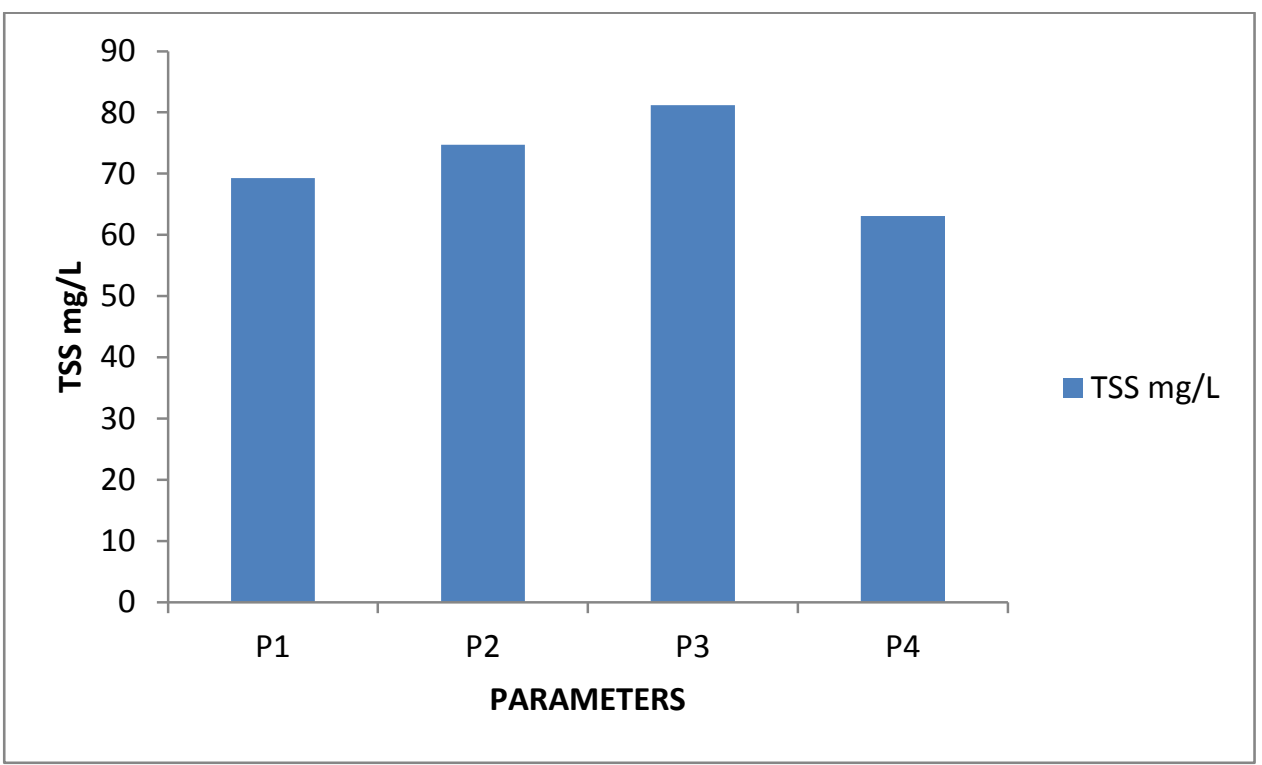

Fig. 5: TSS values for parameter P1, P2, P3, P4 
International Journal of Advances in Scientific Research and Engineering (ijasre), Vol 5 (5), May-2019

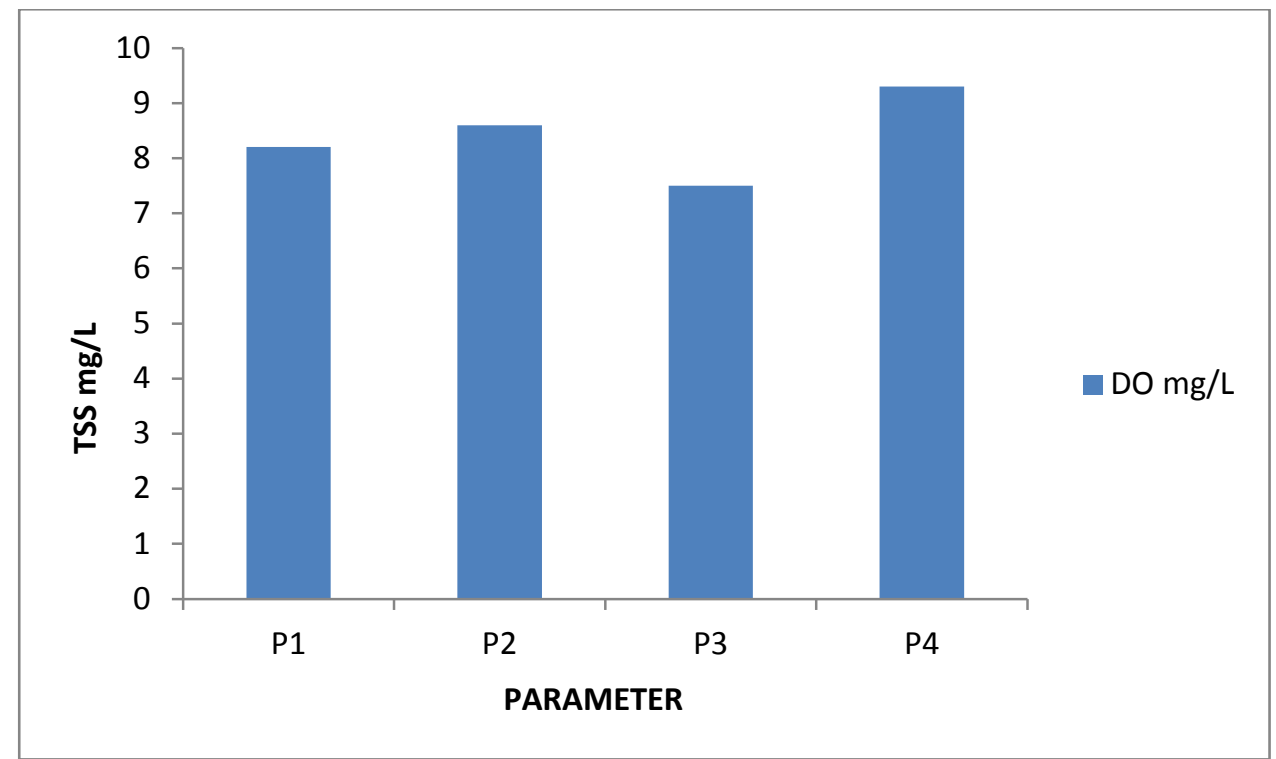

Fig.6: DO values for parameter P1, P2, P3, P4

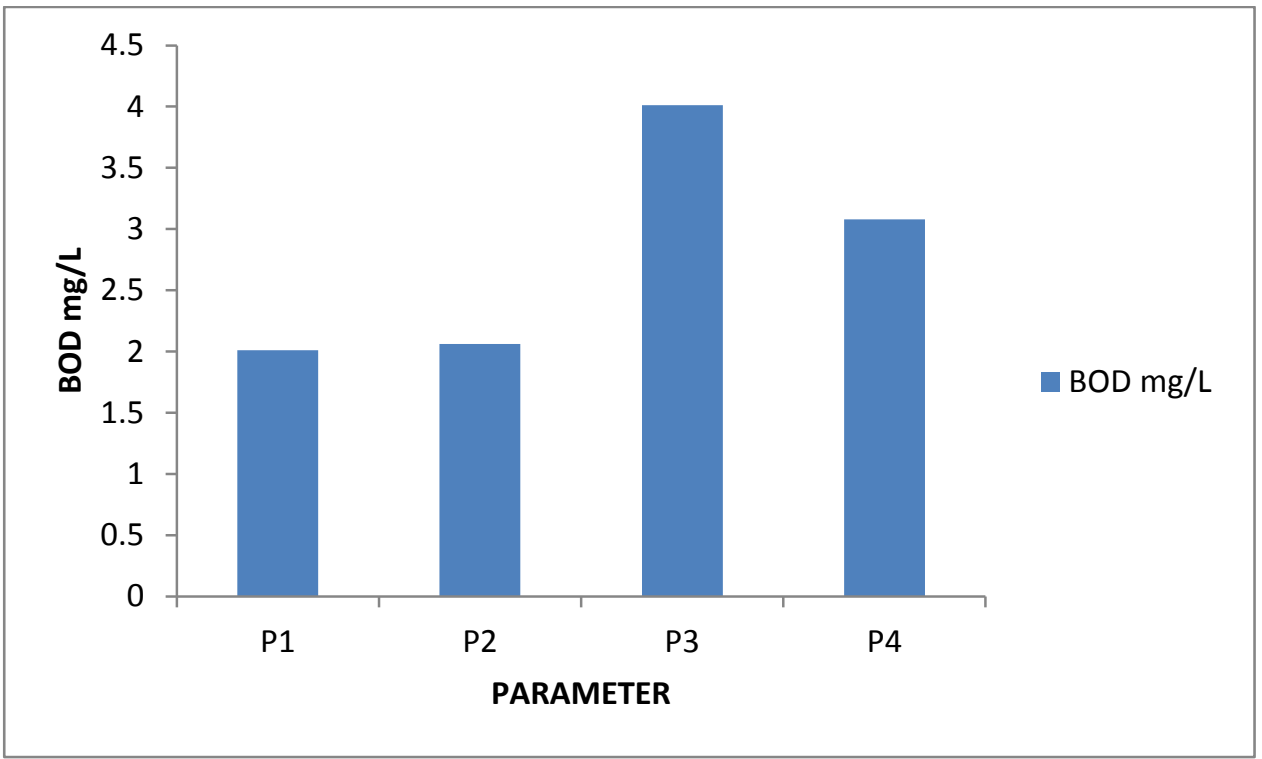

Fig.7: BOD values for parameters P1,P2, P3, P4

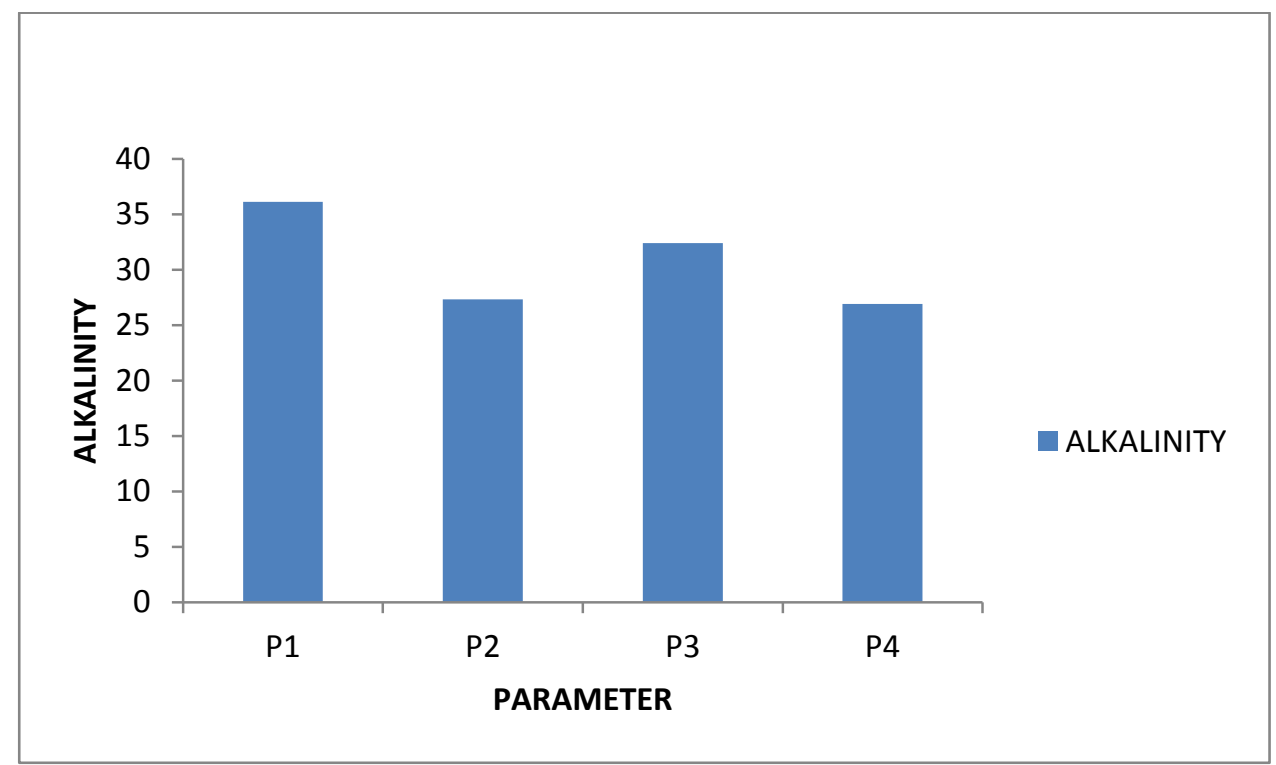

Fig. 8: Alkalinity value for Parameter P1, P2, P3, P4 


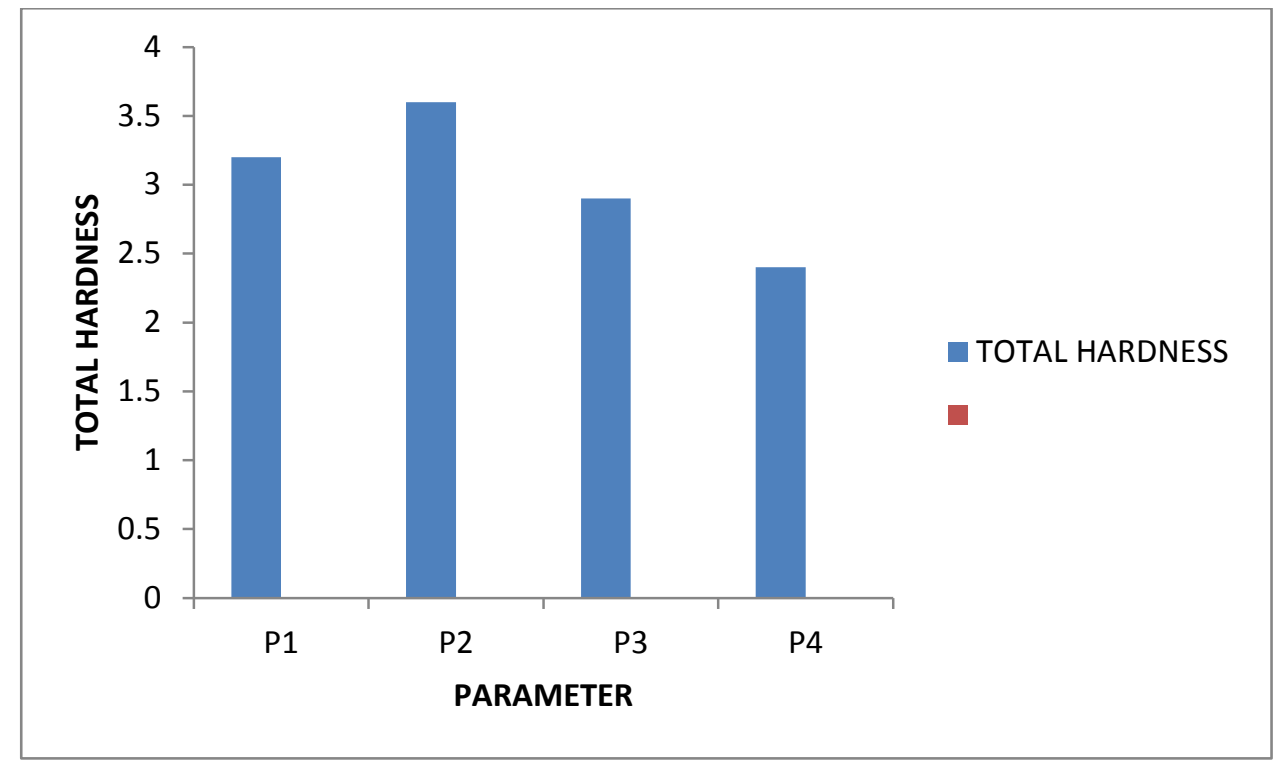

Fig. 9: Total Hardness value for Parameter P1, P2, P3, P4

The table above shows the results for the physic-chemical analysis of the different pond water, pond 1 have the highest $\mathrm{pH}$ of 7.4, while the lowest was recorded in pond 4 (6.8). Fish are known to have an average blood $\mathrm{pH}$ of 7.4 ; therefore pond water with $\mathrm{pH}$ within this average is optimum. It has been reported that the $\mathrm{pH}$ between 6 and 9 was appropriate for increased fish production (Bhatnagar and Devi., 2013). The temperature recorded in this study ranged from 25.0 and 27.0. The optimum water temperature for fish survival has been reported to be between $20-30{ }^{\circ} \mathrm{C}$. Fish is a cold blooded animal, so its temperature is dependent on the temperature of its environment. It changes with the temperature of the surroundings. The temperature changes affect the metabolism and physiology of fishes and so its productivity (Agabire et al., 2015).

The total dissolved solids results gotten in this study ranged from $21.3-28.6 \mathrm{mg} / \mathrm{l}$ which is slightly higher compared to other studies. This could be as result of the fish farmers using majorly artificial feeds for their fish. The total suspended solids are made up of carbonates, bicarbonates, chlorides, phosphates and nitrates of metals such as calcium, magnesium sodium, potassium, magnesium as well as other particles. TSS affects the turbidity of water bodies (Mahananda et al., 2010). It has been reported that effluents water increase TSS (Ehigbonare and Ogunrinde, 2010). The values obtained from this study ranged from 63.1mg/L to $81.2 \mathrm{mg} / \mathrm{L}$. The values obtained relatively low which is good for optimum fish productivity.

DO is known to affect such attributes as growth, survival distribution, behavior and physiology of aquatic organism. The DO obtained from this study ranged between 7.5 to $9.3 \mathrm{mg} / \mathrm{L}$. These values are higher than the WHO acceptable limit of 4-6mg/L. BOD is the measurement of total dissolved oxygen consumed by micro-organism for biodegradation of organic matter. Clerk, (1986), reported that a BOD level above $5 \mathrm{mg} / \mathrm{L}$ is an indication of water pollution. In this study values obtained ranged from 2.01 to $4.01 \mathrm{mg} / \mathrm{L}$.

According to Bhatnagar and Devi, (2013), optimum alkalinity for fish productivity is between 25 to $100 \mathrm{mg} / \mathrm{L}$. The results for alkalinity level gotten in this study ranged from 27.3 to $36.1 \mathrm{mg} / \mathrm{L}$. The values obtained were within this ranged which makes these ponds suitable for fish farming. Total hardness of water is the parameters used to describe the effect of dissolved minerals (mainly $\mathrm{Ca}$ and $\mathrm{Mg}$ ), determining suitability for domestic and industrial purposes which is attributed to the presence of bicarbonates, sulphates, chlorides and nitrates (Singh and Gupta, 2010). The results gotten in this study ranged from 2.4 to $3.2 \mathrm{mg} / \mathrm{L}$, These values are very low which means that fishes may be stressed up due to lack of calcium and magnesium needed for bone and scale formation. It might therefore be necessary to add some calcium, and magnesium supplements since these are necessary for bone and scale formation (Agbaire et al., 2015).

Table 2: Heavy metals concentration of pond water

\begin{tabular}{|c|c|c|c|c|c|}
\hline & $\mathbf{Z n}(\mathbf{m g} / \mathbf{L})$ & $\mathbf{N i}(\mathbf{m g} / \mathbf{L})$ & Pb $(\mathbf{m g} / \mathbf{L})$ & $\mathbf{F e}(\mathbf{m g} / \mathbf{L})$ & $\mathbf{C u}(\mathbf{m g} / \mathbf{L})$ \\
\hline P1 & 0.015 & 0.02 & 0.21 & 0.34 & 0.02 \\
\hline P2 & 0.012 & 0.01 & 0.18 & 0.29 & 0.02 \\
\hline P3 & 0.016 & 0.03 & 0.23 & 0.41 & 0.05 \\
\hline P4 & 0.013 & 0.01 & 0.22 & 0.48 & 0.07 \\
\hline
\end{tabular}


International Journal of Advances in Scientific Research and Engineering (ijasre), Vol 5 (5), May-2019

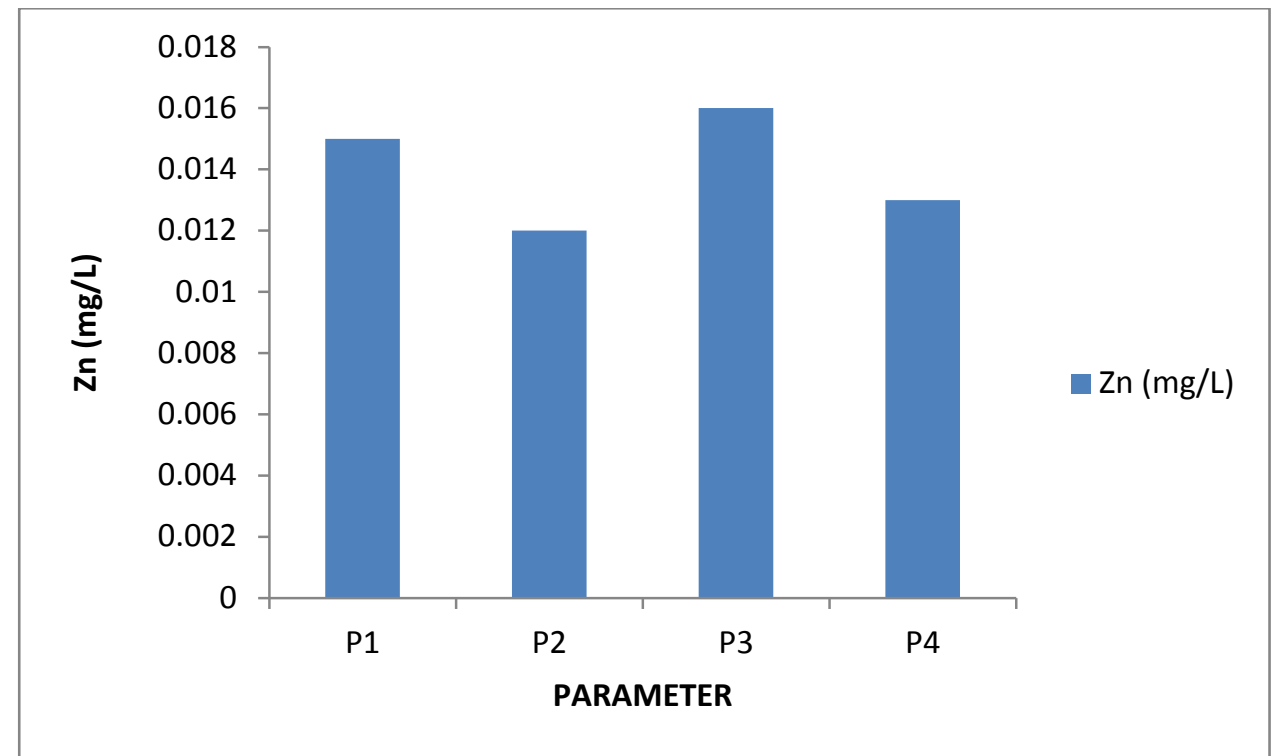

Fig10. Zinc metal concentration in pond water

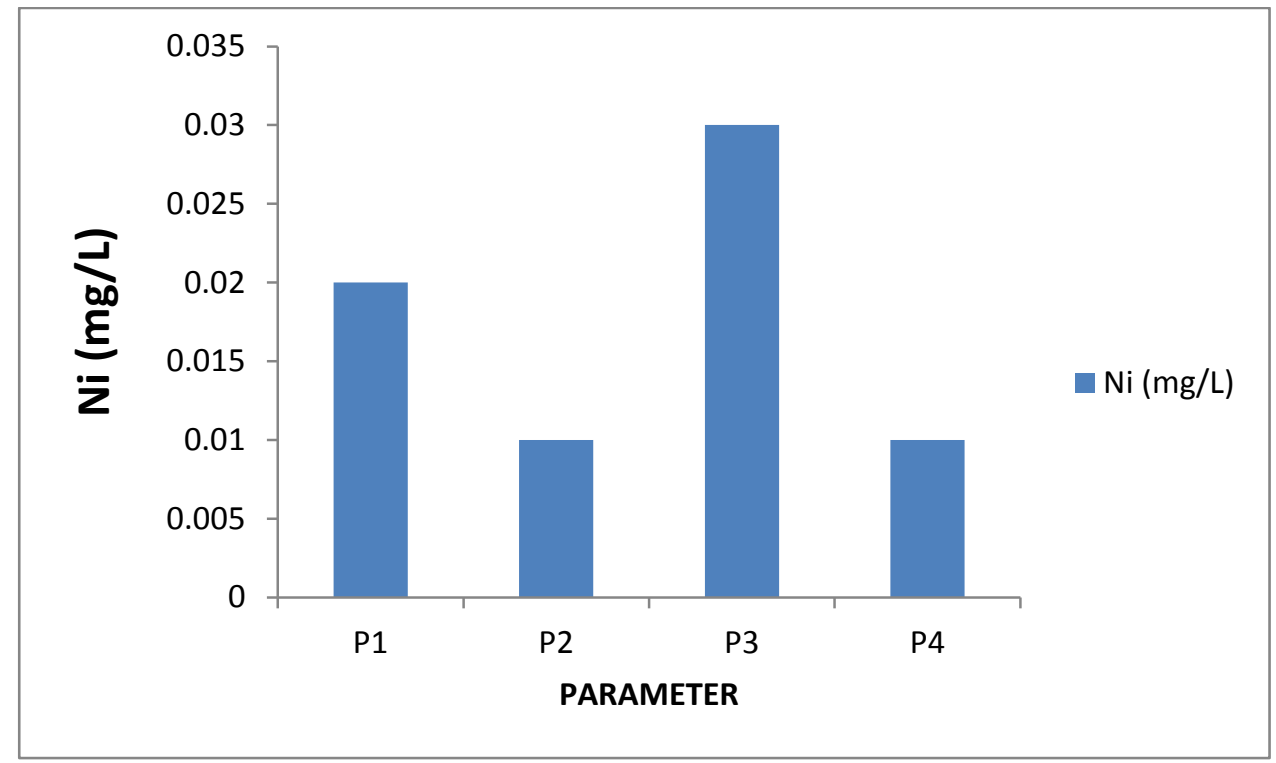

Fig.11: Nickel metal concentration in pond water

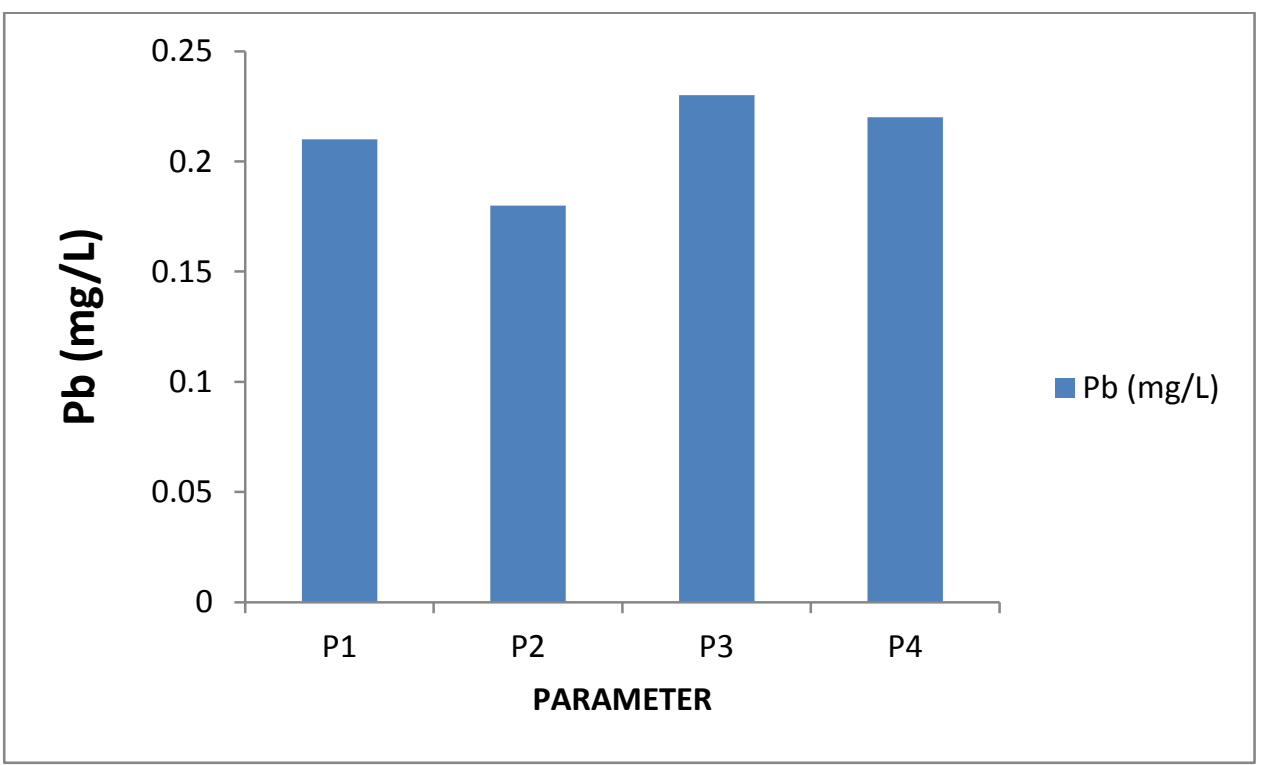

Fig.12: Lead metal concentration in pond water 


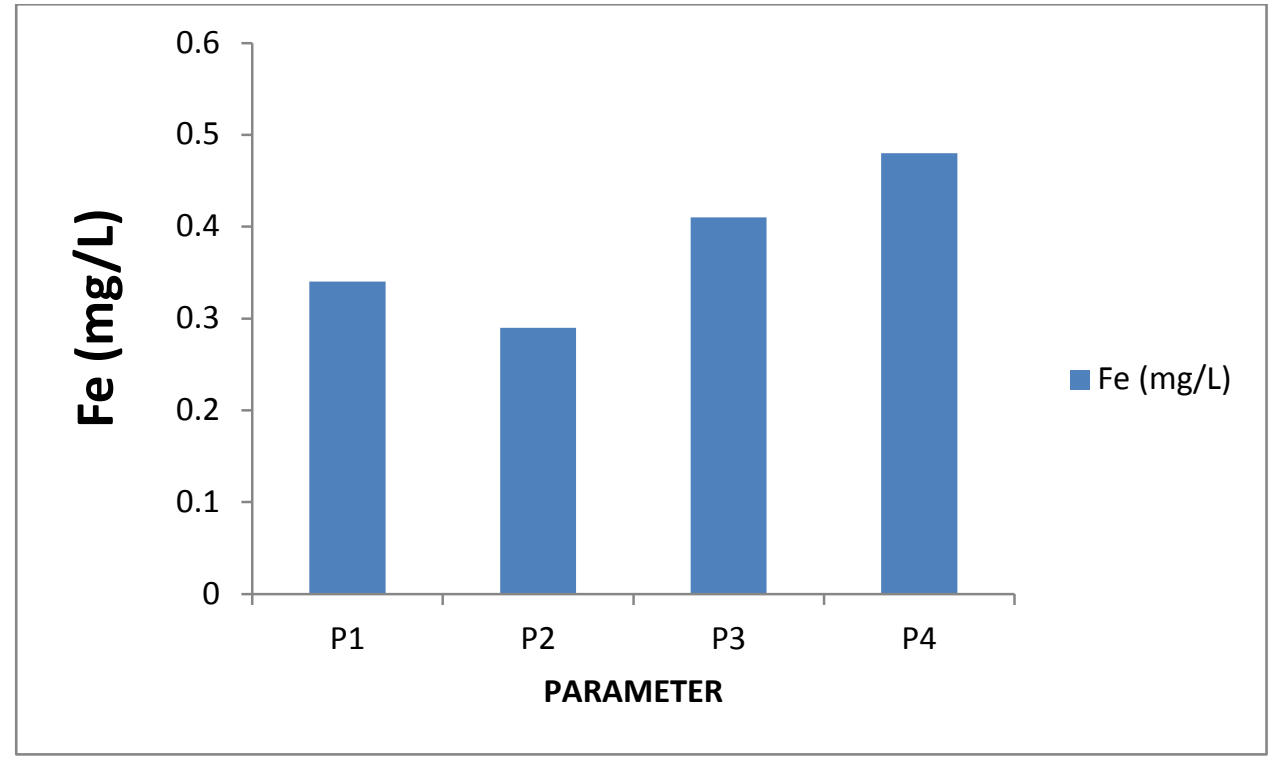

Fig.13: Iron metal concentration in pond water

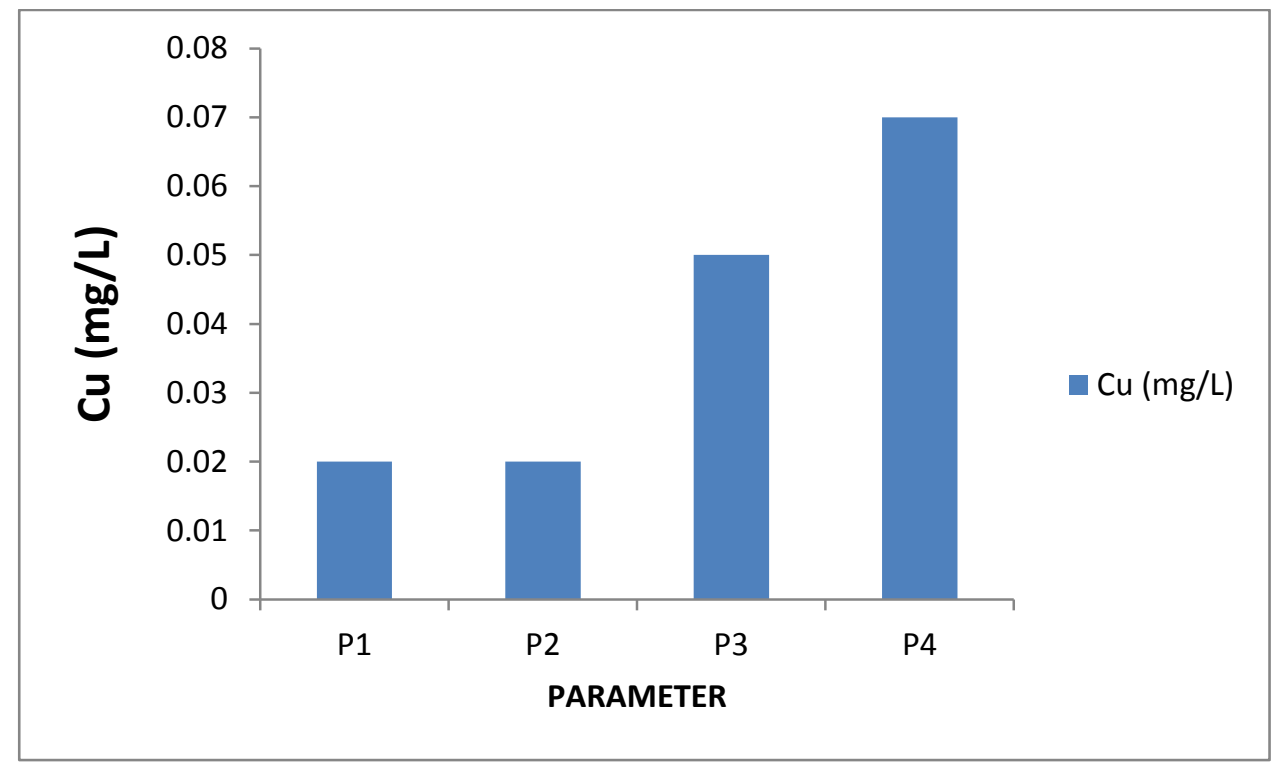

Fig.14: Copper metal concentration in pond water

The table above shows the results for the heavy metals concentration of the different pond water. Zinc, nickel and copper were detected at a very low concentration. Iron has the highest concentration in the different water samples which ranged from 0.34 to $0.48 \mathrm{mg} / \mathrm{L}$, this could be as a result of corrosion of the iron or steel borehole casing and the geology of the location of the pond. Lead was found to be the second highest in the concentration of heavy metals from the water sample at 0.18 to $0.23 \mathrm{mg} / \mathrm{l}$. Lead is found easily in pond water where lead pipes are used to flow water into and out of the pond (Modupe and Indi, 2017). Lead and lead (II) salts and organic lead compounds are considered ecotoxicologically harmful. Other forms of lead could be lead acetate, lead oxide, lead nitrate, and lead carbonate that entered the surface water. Increase in the average concentration of lead in the plants found in the fish pond can lead to the transportation of the lead into the water body.

\section{CONCLUSION AND RECOMMENDATION}

The pond water investigated were in general fit for pond fish productivity except for calcium and magnesium deficiency which could be corrected with some supplement. Also lead and iron concentrations were also high though they were within the WHO permissible limit. It is also important to note that regular water monitoring is worthwhile in order to improve water quality. 


\section{REFERENCES}

[1] Agbaire, Patience Odafevejiri, Akporido, Samuel Omorovie And Emoyan Azaman Fazureen, Hafizan Juahir, Kamaruzzaman Yunus, Azman Azid, Mohd Khairul Amri Kamarudin, Mohd Ekhwan Toriman, Ahmad Dasuki Mustafa, Mohammad Azizi Amran, Che Noraini Che Hasnam, Ahmad Shakir Mohd Saud (2015): Heavy metal in fish: analysis and human health- a review. Jurnal Teknologi (Sciences \& Engineering) 77:1 61-69

[2] Abdel-Baki, A., Dkhil, M., \& Al-Quraishy, S. (2011): Bioaccumulation of Some Heavy Metals In Tilapia Fish Relevant to Their Concentration In Water and Sediment of Wadi Hanifah, Saudi Arabia. African Journal of Biotechnology. 10(13): 2541

[3] Bhatnagar A. and Devi, P. (2013): Water Quality Guidance for the Management of Pond Fish Culture. intl J. Environ. Sci.3 (6) $1980-1993$

[4] Eze, V. C. and Ogbaran I. O. (2010): Microbiological and Physicochemical Characterizes of fish pond water in Ughelli Delta State, Nigeria. Intl. J. Current Res. (8) 082 - 087.

[5] Dunivant, F. M. (2005): Determination of Dissolved Oxygen in Water using the Winkler Method. Environmental Laboratory Exercises for Instrumental Analysis and Environmental Chemistry, John Willey and Sons Inc.

[6] Egbere, O.J, Kadir, A., Oyero, T., Steve, K., Odewumi, O. and Zakari. H. (2008): Bacteriological Quality of Catfish in Jos Metropolis, Nigeria. International Journal of Bioscience, 5 (2), 95-10

[7] Ehigbonare J. E. and Ogunrinde Y. O. (2010): Physicochemical Analysis of Fish Pond Water in Okada and its Environs, Nigeria. Afri. J. of Biotechn. 9 (36): $5922-5928$

[8] Intl. J. of Innov. Res. in Sci. Eng. and Techn. 2 (5) $1781-1788$

[9] Mishsra, M. K. Mishra N. and Pandey, S. N. (2013): An assessment of the Physicochemical Characteristics of Bhanka Pond, Hanumana, Rewa District India.

[11] Onoriode Onos (2015): determination of some physicochemical parameters of water from artificial concrete fish ponds in Abraka and its environs, delta state, Nigeria. international journal of plant, animal and environmental science. vol 5. issn-2231-4490.

[12] Parariya, S. K.. (2012): Analysis of Water Quality Using Physico-Chemical Parameters of Kolura Pond in PostMonsoon Season, October, 2012. Intl J. Chem. Phy. Sci. 1 (2):48- 53.

[13] Shibam Saha, Abhrajyoti Mandal and Diptimoyee Sahoo (2017): Study of physico-chemical parameters of three different urban pond water of Nadia district, West-Bengal, India. International Journal of Fisheries and Aquatic Studies; 5(6): 2327

[14] Singh SN, Gupta ML, Prakash P. (2010): Hydrobiological studies of some eutrophic ponds of Rohtas, Bihar. Journal of Environment and Ecology; 16(2): 457-462

[15] Vosyliene, M. Z., Kazlauskiene, .N and G. Svecevicius (2003): Effect of a Heavy Metal Model Mixture on Biological Parameters of Rainbow Trout (Oncorhynchusmykiss). Environmental Science and Pollution Research 10: $103-107$. 